TAPROBANICA, ISSN 1800-427X. October, 2011. Vol. 03, No. 02: pp. 69-76, 3 pls.

(C) Taprobanica Private Limited, Jl. Kuricang 18 Gd.9 No.47, Ciputat 15412, Tangerang, Indonesia.

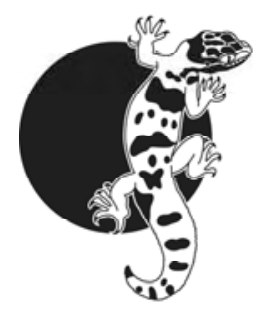

\title{
A PRELIMINARY SURVEY OF THE REPTILE FAUNA IN NILGALA FOREST AND ITS VICINITY, MONARAGALA DISTRICT, SRI LANKA
}

Sectional Editor: John Rudge

Submitted: 30 July 2011, Accepted: 10 October 2011

D. M. S. Suranjan Karunarathna ${ }^{1}$ and A. A. Thasun Amarasinghe ${ }^{2}$

\footnotetext{
${ }^{1}$ Young Zoologists' Association of Sri Lanka, Department of National Zoological Gardens, Sri Lanka. E-mail:dmsameera@gmail.com

${ }^{2}$ Komunitas Konservasi Alam Tanah Timur, Jl. Kuricang 18 Gd.9 No.47, Ciputat 15412, Tangerang, Indonesia

E-mail: thasun.tanahtimur@gmail.com
}

\begin{abstract}
Nilgala Conservation Forest Area (NCFA) is an intermediate zone forest situated in the south east of Sri Lanka. During our four-year study we recorded 70 species of reptiles, which represents about $33 \%$ of the total Sri Lankan reptile fauna. This number includes eighteen species that are recorded from the NCFA for the first time and ten nationally threatened species. Ten unidentified species were also recorded during the survey period. The results of this study indicate that the Nilgala forest area supports a rich reptile faunal diversity. Unfortunately, this important forest is threatened by fire, illegal logging, chena cultivation, rubber plantation, granite rock blasting, gem mining and road kills. It should be considered an area of high conservation priority.
\end{abstract}

Key words: Sri Lanka, Intermediate zone, savannah, reptiles, threats, ecology, conservation

\section{Introduction}

Based on published sources, a total of 210 species of reptiles (Lizards - 97 sp.; Turtles and tortoises 9 sp.; Snakes - 102 sp. and Crocodiles - 2 sp.) have been recorded from Sri Lanka. Of these 210 species $120(57 \%)$ are endemic to the island (de Silva, 2006; Maduwage et al., 2009; ManamendraArachchi et al., 2007; Smith et al., 2008; Somaweera, 2006; Somaweera \& Somaweera, 2009; Wickramasinghe et al., 2007). To date, however, herpetofaunal diversity in the dry and intermediate zone forest areas of the island have not been well studied. The present survey was undertaken to document the reptile fauna of the Nilgala Conservation Forest Area (NCFA), an intermediate zone forest that is one of the largest and most important forest areas in the Monaragala District. Extensive field surveys were conducted from 2004 to 2007. One of the major drawbacks to conserving reptile fauna in Sri Lanka is the lack of knowledge of their distribution and ecology. It is 
therefore essential to gather information on the diversity of the reptile fauna in different areas of the country, as a first step towards conservation. This paper will serve to enhance the current knowledge of the reptile diversity within the NCFA, an area that is at present poorly studied (de Silva et al., 2004; Karunarathna et al., 2006).

\section{Study Area}

NCFA is a forest ecosystem covering 12,432 hectares in the Bibile divisional secretariat. 'Nilgala' literally means 'blue rock'. According to Gunatilleke \& Gunatilleke (1990) the major vegetation type is lowland tropical dry mixed evergreen forest. Commonly found trees include Aralu (Terminalia chebula), Bulu (Terminalia bellirica) and Nelli (Phyllanthus emblica). Other trees such as Terminalia arjuna (Kumbuk), Schleichera oleosa (Kon) and Diospyros ebenum (Kaluwara) are also present. Common shrubs such as Carissa spinarum (Karamba), Zizyphus rugosa (Eraminiya), Lantana camara (Baloliya) and Eupatorium odoratum (Podisingchomaran) occur
(Karunarathna et al., 2008). NCFA is located between $7^{\circ} 08^{`}-7^{\circ} 14^{`} \mathrm{~N}$ and $81^{\circ} 16^{`}-81^{\circ} 20^{`} \mathrm{E}$, approximately $11 \mathrm{~km}$ east of Bibile town (Fig. 1).

Eleven habitat types were identified and sampled during the survey and a brief description of these habitats is given (Table 1). The altitude ranges from $200 \mathrm{~m}$ to $700 \mathrm{~m}$ above sea level within the boundaries of the NCFA. The general climatic conditions in the Nilgala area can be described as moderately cool, turning humid during the northeast monsoon season. The average annual rainfall is around $1,750 \mathrm{~mm}$, with most of the rainfall occurring from December to March, and only occasional rains in other months. The weather gradually becomes very dry from August to December with highest temperatures recorded in August. The mean annual temperature in the NCFA is $28^{\circ} \mathrm{C}$ with a maximum of $32^{\circ} \mathrm{C}$ and minimum of $24^{\circ} \mathrm{C}$. NCFA is also important as a major watershed for Gal Oya and Panmedilla Oya throughout the year. There are several peaks within the NCFA with "Yakun Hela" being the highest (700 m).

Table 1: Description of major habitat types in NCFA and vicinity (see Plate 1 for figures)

Habitat Type

1. Chena

2. Home Gardens

Trees belonging to the family Rutaceae are dominant and grow up to $5 \mathrm{~m}$; scattered bushes present; main cultivation is maize, banana and finger millet. Leaf litter is very low.

Mixed cropping with woody plants like Mangifera indika, Chloroxylon swietenia, Schleichera oleosa, Tamarindus indika; trees grows up to $15 \mathrm{~m}$; shade is about 50\%; leaf litter content is high and wet.

3. Paddy fields Paddy fields are moderate in extent (about 1 acre); wallowing sites are frequent along the fields; field bunds are narrow; Oryza sativa dominant.

Shade $80 \%$ with large tall trees growing up to $20 \mathrm{~m}$; Mangifera ceylanica, Maduca 4. Riverine forests longifolia, Terminalia chebula Diospyros ebenum and Diospyros malabarica are the dominant species; thick wet leaf litter layer available; decaying logs are common.

\begin{tabular}{ll}
\hline 5. Road Sides & $\begin{array}{l}\text { Generally consist of small bushes growing up to } 2 \mathrm{~m} \text {. Species such as Maduca longifolia, } \\
\text { Terminalia bellirica and Mangifera zeylanica can also be found in several areas. }\end{array}$ \\
\hline 6. Rock-outcrops & $\begin{array}{l}\text { Large rock boulders and grassy areas with seasonally moist cascade habitats. Shade 20\% with } \\
\text { tall trees such as Ficus mollis, Diospyros ebenum and Terminalia bellirica. }\end{array}$ \\
\hline
\end{tabular}

7. Savannah forests Prominent trees Terminalia chebula, Terminalia bellirica and Phyllanthus emblica, forest cylindrica).

$1 \mathrm{~m}$ to $2 \mathrm{~m}$ tall and randomly distributed on open soil. Common species are Stachytarpheta

8. Shrub-Bush areas urticaefolia, Ipomoea batatas, Anacardium occidentale, Carissa spinarum, Zizyphus rugosa, Lantana camara and Eupatorium odoratum.

\begin{tabular}{ll}
\hline 9. Small Ponds & $\begin{array}{l}\text { Seasonally flooded, mud ponds, gem pits, agricultural wells, drinking wells, mud pits, clay } \\
\text { pits; shade is maximum } 30 \% .\end{array}$ \\
\hline 10. Streams & $\begin{array}{l}\text { Perennial flowing water bodies, } 1 \mathrm{~m} \text { to } 10 \mathrm{~m} \text { wide; visibility high, and turbidity low. Shade is } \\
\text { about } 40 \% \text { and dominant trees are Diospyros malabarica, Terminalia arjuna and Cynometra } \\
\text { species. }\end{array}$ \\
\hline 11. Tanks & $\begin{array}{l}\text { Open water bodies, covered by macrophytes (25 \%). Maximum water-level April to October } \\
\text { with low water level in other periods. }\end{array}$ \\
\hline
\end{tabular}



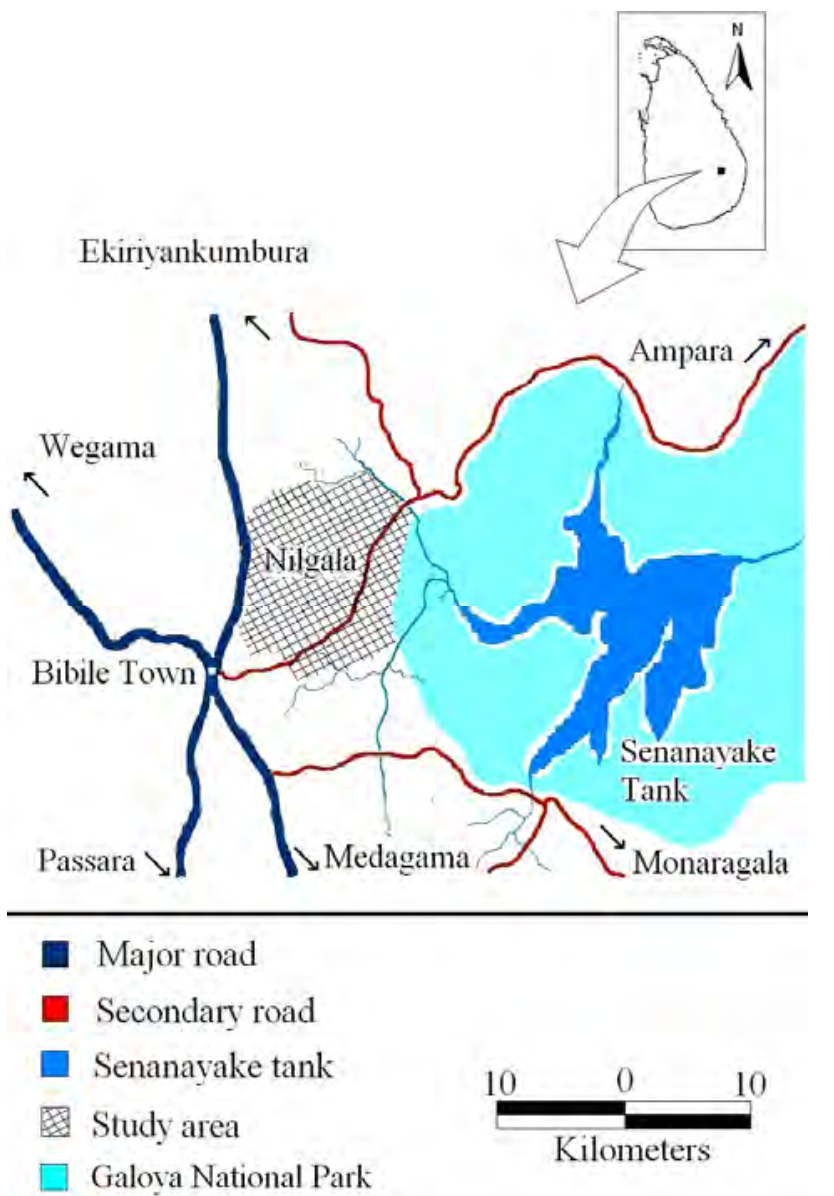

Fig. 1: Map of the Bibile Divisional Secretariat showing the study area. Nilgala Forest is in cross-bars.

\section{Material and Methods}

The present study was carried out from January 2004 to December 2007 with a total of 68 field days (8 hrs / day) covering both the wet and dry seasons. General area surveys were carried out in eleven different habitat types within the NCFA. Surveys were conducted by both day and night. Flashlights were used at night. All habitats including water bodies, under rocks, logs and decaying vegetation, and trees and bushes up to $5 \mathrm{~m}$ were thoroughly searched for the presence of reptiles. All collected specimens were examined carefully and recorded prior to being released back to their original point of capture. Basic environmental parameters such as temperature and humidity were recorded at locations where specimens were observed. Rainfall data were obtained from the nearest weather station (Welipitiya Coconut Plantation, Badulla) from the National Meteorological Department in Colombo. Road kills were examined but not collected. Most road kills were extensively damaged and thus are not included in the tables as they could not be identified to the species level. The specimens were identified through the use of field guides and identification keys given by Boulenger (1890), Deraniyagala (1953 \& 1955), Das \& de Silva (2005), De Silva (1980), de Silva (1990), Greer (1991), Smith (1935 \& 1943), Taylor (1950), Wall (1921), Whitaker \& Captain (2004). Threat category was determined according to the National Red List (IUCNSL \& MENR, 2007). Forest type, floral identification and nomenclature were done using Ashton et al. (1997); Gunatilleke \& Gunatilleke (1990) and Senaratna (2001).

\section{Results and Discussion}

A previous study of the reptile fauna of NCFA was conducted over three months of 2003 by de Silva et al. (2004). Their study recorded 40 species of reptiles, but did not include several common species of reptile fauna from the area. Hettige et al. (2000) recorded 29 species of reptile in a survey of the fauna of Gal Oya National Park. The present fouryear survey recorded 70 known species of reptile and a further 10 unidentified species. The results are presented in Table 2. The reptiles recorded belong to 17 families and 49 genera. The 10 unidentified species, all of which might be new to science, belong to the genera Calotes, Cnemaspis, Cyrtodactylus, Dendrelaphis, Hypnale, Nessia, Ramphotyphlops, Rhinophis, Typhlops and Xenochrophis.

The following species were recorded for the first time in NCFA; Ahaetulla pulverulenta, Aspidura brachyorrhos, Boiga beddomei, B. trigonata, Chrysopelea taprobonica, Dendrelaphis bifrenalis, Dryocalamus nympha, Liopeltis calamaria, Oligodon sublineatus, Bungarus ceylonicus, Calliophis melanurus, Cylindrophis maculatus, Rhinophis oxyrhynchus, Cnemaspis podihuna, Geckoella yakhuna, Hemidactylus leschenaulti, Dasia halianus and Eutropis bibronii (see Karunarathna \& Karunarathna, 2005; Karunarathna et al., 2005).

These records show that at least 33\% of Sri Lanka's extant reptiles are present in the NCFA. There is also a significant representation of the country's amphibians (see Karunarathna et al., 2008). We believe this high diversity in intermediate zone forest habitats is mainly due to the availability of a number of microhabitats, including man-modified habitats that are favorable to reptiles. According to these results, NCFA has the highest reptile richness in an Intermediate or Dry zone forest of Sri Lanka.

Of the total of 70 species 25 (36\%) are endemic to Sri Lanka. The survey recorded 5 (7\%) data 
deficient species, 13 (19\%) near threatened species and $10(14 \%)$ threatened species. The family with the largest number of species present is Colubridae (26 sp.), followed by Gekkonidae (13 sp.), Scincidae (7 sp.), Agamidae (5 sp.), Elapidae (4 $s p$.), Viperidae (3 $s p$.) and Varanidae (2 sp.). The leading number of endemic species is in Gekkonidae (9 sp.), Colubridae (6 sp.), Agamidae, Scincidae and Uropeltidae (2 sp. each), Elapidae, Viperidae, Trionychidae and Cylindrophidae (1 sp. each) respectively (Table 2). In NCFA aquatic colubrids are frequently found and 3 out of the 6 species recorded from the country occur. According to Vogel \& David (2006), specimens of Xenochrophis cf. piscator from Sri Lanka are actually an undescribed species.

When considering the 80 species (including undescribed) by their primary mode of living there are $34(42.5 \%)$ terrestrial, 28 (35\%) arboreal, 8 (10\%) aquatic and 10 (12.5\%) fossorial species. In terms of the species diversity in each habitat type, the highest species richness occurred in Home Gardens (45), followed by Rock-outcrops (33), Chena (30), Shrub/Bush habitats (30), Riverine forests (25), Road Sides (22), Savannah forest (21), Paddy fields (15). Small Ponds, Streams and Tanks (8 species each) showed the lowest species richness. The high species richness in the Home Gardens habitat may be due to the high amount of leaf litter, shade, micro-habitats and also the abundant availability of food items such as small vertebrates and invertebrates on which to feed. The highest number of endemic species was found in Home Gardens (14), followed by Rock-outcrops (13), Riverine forests (11), Shrub/Bush areas (8), Savannah forest (5), Chena (5), Road Sides (4), Paddy fields (3) and Tanks (2). Small Ponds and streams (1 species each) showed the lowest number of endemic species.

\section{Conclusion and Recommendation}

During the survey period several threats to the reptile fauna of the NCFA were observed and recorded. These included irresponsible forest fires, illegal logging, extensive use of chemicals for agriculture including rubber plantations, forest clearing for chena cultivation, gem mining, granite rock blasting and road kills. People living around the NCFA frequently use fire to clear the underbrush, prepare the ground for the next cultivation cycle and hunt for animals (Karunarathna et al., 2005). These fires are very frequent in the months of August and September and destroy the habitats suitable to the reptile fauna.
Illegal logging activities seriously impact the quality of the forests. The local communities are involved in paddy and chena cultivation in the vicinity of the NCFA. These people use chemical fertilizers, pesticides and weedicides. Another significant threat to the reptile fauna of the area is road kills. Many animals that attempt to cross the Bibile Ampara main road, which cuts across the NCFA end up as road kills. The research team has observed and recorded that reptile mortality is particularly high on this road after rains (Karunarathna et al., 2006).

This investigation into the reptiles of the NCFA and its vicinity clearly shows that the Nilgala Forest is an important location in terms of herpetofaunal diversity (Fig. 2). Formal and informal education should be developed, not only in primary and secondary schools but also in driving schools and in universities to promote knowledge of the natural environment of the area. It is also evident that the NCFA acts as an important refuge for endemic, rare and threatened reptiles in the Intermediate zone of the Uva province. The NCFA and its surrounding habitats have been understudied, a fact which is evident from the documenting of 18 species new to the NCFA during this survey. Our preliminary study clearly shows that there is a need to conduct a comprehensive reptile survey in the NCFA. Such a study will help in compiling a more complete list of reptiles and also aid in determining the status of the different species within the NCFA. The latter may be critical because of the imminent anthropogenic pressures within and around the NCFA.

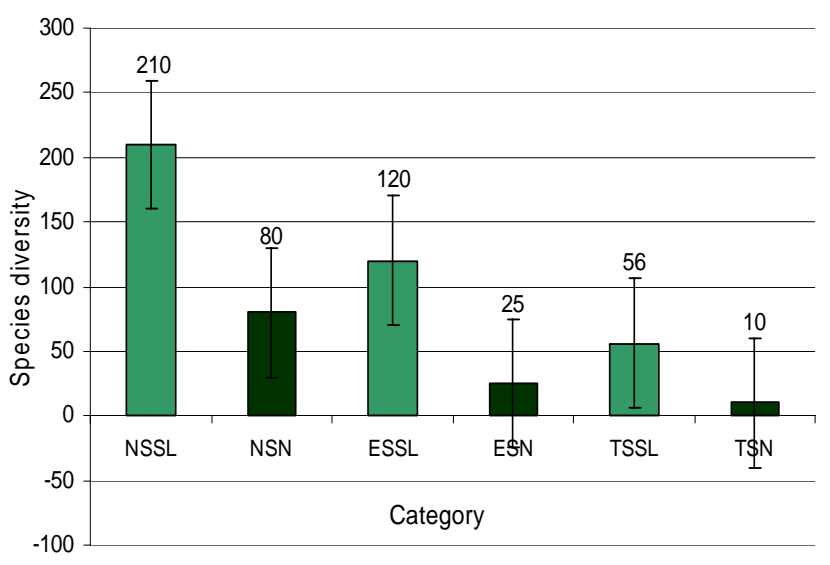

Fig. 2: Comparison of reptile diversity of Sri Lanka and NCFA. (Abbreviations: NSSL - total number of reptile species in Sri Lanka; NSN - total number of reptile species in Nilgala (including undescribed species); ESSL - number of endemic species to Sri Lanka; ESN number of endemic species in Nilgala; TSSL - number of threatened species in Sri Lanka and TSN - number of threatened species in Nilgala). 
Table 2: Reptile fauna recorded from the Nilgala Forest Area and their habitats. Abbreviations: $\mathrm{Chena}(\mathrm{CH})$; Home Gardens (HG); Paddy fields (PF); Riverine forests (RF); Road Sides (RS); Rock-outcrops (RO); Savannah forests (SF); Shrub / Bush areas (SB); Small Ponds (SP); Streams (ST); Tanks (TK); Endemic (E); Most Probably Endemic (E?); Threatened (T); Near Threatened (NT); Data Deficient (DD).

\begin{tabular}{|c|c|c|c|c|c|c|c|c|c|c|c|c|c|}
\hline & Scientific Names and Author citation & Status & $\mathbf{C H}$ & HG & PF & RF & RS & RO & SF & SB & SP & ST & TK \\
\hline \multicolumn{14}{|c|}{ Family - Boidae } \\
\hline 1 & Python molurus (Linnaeus, 1758) & & & + & & & + & & & + & + & + & + \\
\hline \multicolumn{14}{|c|}{ Family - Colubridae } \\
\hline 2 & Ahaetulla nasuta (Lacépède, 1789) & & + & + & + & + & + & + & & + & & & \\
\hline 3 & Ahaetulla pulverulenta (Duméril et al., 1854) & NT & + & & + & & & & & + & & & \\
\hline 4 & Amphiesma stolatum (Linnaeus, 1758) & & & & + & & & & + & + & + & + & \\
\hline 5 & Aspidura brachyorrhos (Boie, 1827) & $\mathrm{E} / \mathrm{NT}$ & & + & & & + & & & & & & \\
\hline 6 & Atretium schistosum (Daudin, 1803) & & & & + & + & & & & & & + & + \\
\hline 7 & Boiga beddomei (Wall, 1909) & DD & & + & & + & & & & & & & \\
\hline 8 & Boiga ceylonensis (Günther, 1858) & & + & + & & & & & & + & & & \\
\hline 9 & Boiga forsteni (Duméril et al., 1854) & & & + & & & + & & & + & & & \\
\hline 10 & Boiga trigonata (Schneider, 1802) & & + & + & & & & & & + & & & \\
\hline 11 & Chrysopelea ornata (Shaw, 1802) & NT & & + & & + & & & & & & & \\
\hline 12 & Chrysopelea taprobonica Smith, 1943 & $\mathrm{E} / \mathrm{T}$ & + & & & & & + & & & & & \\
\hline 13 & Coelognathus helena (Daudin, 1803) & & & + & + & + & & & + & & & & \\
\hline 14 & Dendrelaphis bifrenalis (Boulenger, 1890) & E & & & & & & + & & + & & & \\
\hline 15 & Dendrelaphis tristis (Daudin, 1803) & & + & + & & & + & & & + & & & \\
\hline 16 & Dendrelaphis cf. schokari & $\mathrm{E}$ ? & & + & & & & + & & & & & \\
\hline 17 & Dryocalamus nympha (Daudin, 1803) & NT & & & & + & & + & & & & & \\
\hline 18 & Liopeltis calamaria (Günther, 1858) & $\mathrm{T}$ & & & & & + & & & & & & \\
\hline 19 & Lycodon aulicus (Linnaeus, 1758) & & + & + & & + & & + & & + & & & \\
\hline 20 & Lycodon osmanhilli Taylor, 1950 & E & & + & & & & & & + & & & \\
\hline 21 & Lycodon striatus (Shaw, 1802) & & + & + & & & & + & & + & & & \\
\hline 22 & Macropisthodon plumbicolor (Cantor, 1839) & NT & & + & & & & + & & & & & \\
\hline 23 & Oligodon arnensis (Shaw, 1802) & & + & & & & & + & & + & & & \\
\hline 24 & Oligodon sublineatus Duméril et al., 1854 & E & + & + & & + & & + & & & & & \\
\hline 25 & Oligodon taeniolatus (Jerdon, 1853) & & + & & & & + & & & & & & \\
\hline 26 & Ptyas mucosus (Linnaeus, 1758) & & + & + & + & & + & + & + & + & + & & \\
\hline 27 & Sibynophis subpunctatus (Duméril et al., 1854) & & + & + & + & & & & + & & & & \\
\hline 28 & Xenochrophis asperrimus (Boulenger, 1891) & $\mathrm{E}$ & & & + & & & & & & + & & + \\
\hline 29 & Xenochrophis cf. piscator & $\mathrm{E}$ ? & & & & & & & & & + & + & + \\
\hline \multicolumn{14}{|c|}{ Family - Elapidae } \\
\hline 30 & Bungarus caeruleus (Schneider, 1801) & & + & + & & + & + & + & + & + & & & \\
\hline 31 & Bungarus ceylonicus Günther, 1864 & $\mathrm{E} / \mathrm{NT}$ & & + & & & & & & & & & \\
\hline 32 & Calliophis melanurus (Shaw, 1802) & NT & & & & & + & & + & & & & \\
\hline 33 & Naja naja (Linnaeus, 1758) & & & & + & & + & & + & + & & & \\
\hline \multicolumn{14}{|c|}{ Family - Typhlophidae } \\
\hline 34 & Ramphotyphlops cf. braminus & $\mathrm{E}$ ? & & + & & & & & & + & & & \\
\hline 35 & Typhlops cf. mirus & $\mathrm{E}$ ? & & + & & + & & + & & & & & \\
\hline \multicolumn{14}{|c|}{ Family - Cylindrophidae } \\
\hline 36 & Cylindrophis maculatus (Linnaeus, 1758) & $\mathrm{E} / \mathrm{NT}$ & & + & + & + & & & & + & & & \\
\hline \multicolumn{14}{|c|}{ Family - Uropeltidae } \\
\hline 37 & Pseudotyphlops philippinus (Müller, 1832) & $\mathrm{E} / \mathrm{DD}$ & & + & & & + & & & + & & & \\
\hline 38 & Rhinophis oxyrhynchus (Schneider, 1801) & $\mathrm{E} / \mathrm{DD}$ & & & & & & & + & + & & & \\
\hline 39 & Rhinophis cf. punctatus & E? & & & & & + & & & & & & \\
\hline \multicolumn{14}{|c|}{ Family - Viperidae } \\
\hline 40 & Daboia russelii (Shaw \& Nodder, 1797) & & + & + & & & + & & & + & & & \\
\hline 41 & Hypnale hypnale (Merrem, 1820) & & + & & + & & & & & + & & & \\
\hline 42 & Hypnale cf. zara & $\mathrm{E}$ ? & & + & & + & + & & & & & & \\
\hline 43 & $\begin{array}{l}\text { Trimeresurus trigonocephalus } \\
\text { (Sonnini \& Latreille, 1801) }\end{array}$ & E & & + & & + & & + & & & & & \\
\hline
\end{tabular}




\begin{tabular}{|c|c|c|c|c|c|c|c|c|c|c|c|c|c|}
\hline & Scientific Names and Author citation & Status & $\mathbf{C H}$ & HG & PF & RF & RS & RO & SF & SB & SP & ST & TK \\
\hline \multicolumn{14}{|c|}{ Family - Crocodylidae } \\
\hline 44 & Crocodylus palustris Lesson, 1831 & & & & & & & & & & & + & + \\
\hline \multicolumn{14}{|c|}{ Family - Bataguridae } \\
\hline 45 & Melanochelys trijuga (Schweigger, 1814) & NT & & & + & & & & & & + & + & + \\
\hline \multicolumn{14}{|c|}{ Family - Testudinidae } \\
\hline 46 & Geochelone elegans (Schoepff, 1795) & $\mathrm{T}$ & + & & & & & & + & & + & & \\
\hline \multicolumn{14}{|c|}{ Family - Trionychidae } \\
\hline 47 & Lissemys ceylonensis (Gray, 1856) & $\mathrm{E} / \mathrm{T}$ & & & + & & & & & & & + & + \\
\hline \multicolumn{14}{|c|}{ Family - Agamidae } \\
\hline 48 & Calotes calotes (Linnaeus, 1758) & & & + & & & + & & & + & & & \\
\hline 49 & Calotes ceylonensis Müller, 1887 & $\mathrm{E} / \mathrm{T}$ & + & + & & & + & & & + & & & \\
\hline 50 & Calotes versicolor (Daudin, 1802) & & + & + & & & + & + & + & + & & & \\
\hline 51 & Calotes cf. liolepis & E? & & & & + & & & & & & & \\
\hline 52 & Otocryptis nigristigma Bahir \& Silva, 2005 & $\mathrm{E}$ & & + & & + & & & & & & & \\
\hline 53 & Sitana ponticeriana Cuvier, 1829 & & + & & & & & & + & + & & & \\
\hline \multicolumn{14}{|c|}{ Family - Chamaeleonidae } \\
\hline 54 & Chamaeleon zeylanicus Laurenti, 1768 & NT & & & & & & + & & & & & \\
\hline \multicolumn{14}{|c|}{ Family - Gekkonidae } \\
\hline 55 & Calodactylodes illingworthorum Deraniyagala,1953 & $\mathrm{E} / \mathrm{T}$ & & & & & & + & + & & & & \\
\hline 56 & $\begin{array}{l}\text { Cnemaspis alwisi Wickramasinghe \& Munindradsa, } \\
2007\end{array}$ & $\mathrm{E} / \mathrm{DD}$ & & + & & + & & + & & & & & \\
\hline 57 & $\begin{array}{l}\text { Cnemaspis kumarasinghei Wickramasinghe \& } \\
\text { Munindradsa, } 2007\end{array}$ & $\mathrm{E} / \mathrm{DD}$ & & + & & + & & + & & & & & \\
\hline 58 & Cnemaspis podihuna Deraniyagala, 1944 & $\mathrm{E} / \mathrm{T}$ & & & & + & & & & & & & \\
\hline 59 & Cnemaspis cf. tropidogaster & E? & & & & & & + & & & & & \\
\hline 60 & Cyrtodactylus cf. fraenatus & $\mathrm{E} ?$ & & & & + & & + & & & & & \\
\hline 61 & Geckoella triedrus (Günther, 1864) & $\mathrm{E} / \mathrm{NT}$ & & & & + & & + & & & & & \\
\hline 62 & Geckoella yakhuna (Deraniyagala, 1945) & $\mathrm{E}$ & & & & + & & + & + & & & & \\
\hline 63 & Gehyra mutilata (Wiegmann, 1834) & & + & + & & & & & & & & & \\
\hline 64 & Hemidactylus parvimaculatus Deraniyagala, 1953 & & + & + & & & & + & & & & & \\
\hline 65 & Hemidactylus depressus Gray, 1842 & $\mathrm{E}$ & & + & & + & & + & & & & & \\
\hline 66 & Hemidactylus frenatus Schlegel, 1836 & & + & + & & & & + & & & & & \\
\hline 67 & Hemidactylus leschenaulti Duméril \& Bibron, 1836 & & + & & & & + & & + & & & & \\
\hline 68 & Hemidactylus hunae Deraniyagala, 1937 & $\mathrm{E} / \mathrm{NT}$ & & & & & & + & + & & & & \\
\hline 69 & Hemidactylus lankae Deraniyagala, 1953 & $\mathrm{E}$ & + & + & & & & + & & + & & & \\
\hline \multicolumn{14}{|c|}{ Family - Lacertidae } \\
\hline 70 & Ophisops leschenaulti lankae (Deraniyagala, 1953) & $\mathrm{T}$ & & & & & & + & + & & & & \\
\hline \multicolumn{14}{|c|}{ Family - Scincidae } \\
\hline 71 & Dasia halianus (Haly \& Nevill, 1887) & $\mathrm{E} / \mathrm{NT}$ & & & & & + & & + & & & & \\
\hline 72 & Lankascincus fallax (Peters, 1860) & $\mathrm{E}$ & + & + & & + & & + & & + & & & \\
\hline 73 & Lygosoma punctata (Gmelin, 1799) & & + & + & & & & & + & & & & \\
\hline 74 & Eutropis beddomii (Jerdon, 1870) & $\mathrm{T}$ & & + & & & & & + & & & & \\
\hline 75 & Eutropis bibronii (Gray, 1838) & $\mathrm{T}$ & & & & & & & + & & & & \\
\hline 76 & Eutropis carinata lankae (Deraniyagala, 1953) & & + & + & & & & + & & + & & & \\
\hline 77 & Eutropis macularia (Blyth, 1853) & & & & & & & + & & & & & \\
\hline 78 & Nessia cf. sarasinorum & E? & & + & & + & & & & & & & \\
\hline \multicolumn{14}{|c|}{ Family - Varanidae } \\
\hline 79 & Varanus bengalensis (Daudin, 1802) & & + & + & + & & + & + & + & + & & & \\
\hline 80 & Varanus salvator (Laurenti, 1768) & & + & + & + & + & + & & & & + & + & + \\
\hline
\end{tabular}

\section{Acknowledgements}

The authors wish to thank Asha de Vos (IUCN - Sri Lanka) for reviewing the manuscript. We would also like to thank Mendis Wickramasinghe, Vimukthi Weeratunga, Chamila Soysa, Dilshad
Jemzeed, Toshan Peiris, Asanka Udayakumara, Anushka Kumarasinghe, Ramyanath Sirimanna, Tiran Abeyawardena, Panduka Silva, Dimuthu Wickramasinghe, Nadeesh Gamage and Devaka Jayamanna (YZA) for their kind help during the 
field visits to NCFA. Finally, we would like to thank Somapala, Chaminda, Champika, Kulatunga, Thissami, Ukkumenika, Asanka, Samantha, Punchibanda, Tikiri, Raja and Lal (Villagers of Pitakumbura) for field activity accommodation in the Nilgala Area.

\section{Literature Cited}

Ashton, M., C. V. S Gunatileke, N. De Zoysa, M. D. Dassanayake, N. Gunatileke and S. Wijesundara, 1997. A field guide to the common trees and shrubs of Sri Lanka. Wildlife Heritage Trust of Sri Lanka: 432.

Boulenger, G. A., 1890. The Fauna of British India including Ceylon and Burma. Reptilia and Batrachia. Taylor and Francis, London: 541.

Deraniyagala, P. E. P., 1953. A Colored Atlas of some vertebrates from Ceylon, Tetrapod Reptilia - Vol. II. National Museums of Sri Lanka: 101.

Deraniyagala, P. E. P., 1955. A Colored Atlas of Some Vertebrates from Ceylon, Serpentoid Reptilia - Vol. III. National Museums of Sri Lanka: 121.

Das, I. and A. de Silva, 2005. Photographic guide to the Snakes and other Reptiles of Sri Lanka. New Holland Publishers: 144.

de Silva, A., 1990. Colour Guide to the snakes of Sri Lanka. R and A Publishing Ltd., Avon: 130.

de Silva, A., 2006. Current status of the Reptiles of Sri Lanka, In: Fauna of Sri Lanka: Status of Taxonomy, Research and Conservation, Bambaradeniya, C. N. B. (ed.). IUCN Sri Lanka, Colombo: 134-163.

de Silva, A., A. M. Bauer, C. C. Austin, S. Goonewardena, Z. Hawke and D. V. Vanneck, 2004. The diversity of Nilgala forest, Sri Lanka, with special reference to its herpetofauna. Lyriocephalus, 5(1\&2): 164-182.

De Silva, P. H. D. H., 1980. Snakes Fauna of Sri Lanka, with special reference to skull, dentition and venom in snakes. National Museums of Sri Lanka: 472.

Greer, A. E., 1991. Lankascincus, a new genus of Scincid lizards from Sri Lanka with descriptions of three new species. Journal of Herpetology, 25 (1): 5964.

Gunatilleke, I. A. U. N. and C. V. S. Gunatilleke, 1990. Distribution of floristic richness and its conservation in Sri Lanka. Conservation Biology, 4 (1): 21-31.
Hettige, U. S. B., L. J. M. Wickramasinghe, T. G. M. Priyadarshana, K. Gunawardena, L. I Perera and A. Manorathna, 2000. Fauna of Gal Oya National Park. Sri Lanka Naturalist, 3 (4): 55-61.

IUCNSL \& MENR, 2007. The 2007 Red List of threatened Fauna and Flora of Sri Lanka. IUCN Sri Lanka: 148.

Karunarathna, D. M. S. S. and D. M. G. N. Karunarathna, 2005. An unusual behavior of Otocryptis nigristigma Bahir \& Silva, 2005 (Reptilia: Agamidae) observed at Nilgala forest in Sri Lanka. Sri Lanka Naturalist, 7 (1\&2): 21-22.

Karunarathna, D. M. S. S., U. T. I. Abeywardena, M. D. C. Asela, D. M. G. N. Karunarathna, D. G. R. Sirimanna and A. A. T. Amarasinghe, 2005. First record of the Chamaeleo zeylanicus Laurenti, 1768 (Reptilia: Chamaeleonidae) from the Nilgala forest in Sri Lanka. Loris, 24 (1\&2): 18-20.

Karunarathna, D. M. S. S., A. A. T. Amarasinghe, U. T. I. Abeywardena, M. D. C. Asela and D. G. R. Sirimanna, 2006. Preliminary study on Herpetofauna diversity of Nilgala forest area in Monaragala district, Sri Lanka. Proceeding of the $11^{\text {th }}$ International Forestry and Environment Symposium of University of Sri Jayewardenepura, Sri Lanka: 74.

Karunarathna, D. M. S. S., U. T. I. Abeywardena, M. D. C. Asela and L. D. C. B. Kekulandala, 2008. A preliminary survey of the Amphibian fauna in Nilgala Forest area and its vicinity, Monaragala District in Sri Lanka. Herpetological Conservation and Biology, 3 (2): 264-272.

Maduwage, K., A. Silva, K. Manamendra-Arachchi and R. Pethiyagoda, 2009. A taxonomic revision of the South Asian hump-nosed pit vipers (Squamata: Viperidae: Hypnale). Zootaxa, 2232: 1-28.

Manamendra-Arachchi, K., S. Batuwita and R. Pethiyagoda, 2007. A taxonomical revision of the Sri Lankan day-geckos (Reptilia: Gekkonidae: Cnemaspis), with description of new species from Sri Lanka and India. Zeylanica, 7 (1): 9-122.

Senaratna, L. M., 2001. A Check List of the Flowering Plants of Sri Lanka. National Science Foundation, Sri Lanka: 342.

Smith M. A., 1935. The Fauna of British India including Ceylon and Burma. Reptilia and Amphibia Vol. II Sauria. Taylor and Francis, London: 440. 
Smith, M. A., 1943. The Fauna of British India, Ceylon and Burma, Including the Whole of the IndoChinese Sub-Region. Reptilia and Amphibia - Vol. III Serpentes. Taylor and Francis, London: 583.

Smith, E. N., K. Manamendra-Arachchi and R. Somaweera, 2008. A new species of Coral snake of the genus Calliophis (Squamata: Elapidae) from the Central Province of Sri Lanka. Zootaxa, 1847: 19-33.

Somaweera, R., 2006. Snakes of Sri Lanka (Sinhala text). Wildlife Heritage Trust of Sri Lanka: 297.

Somaweera, R. and N. Somaweera, 2009. Lizards of Sri Lanka: A colour guide with field keys. Edition Chimaira, Frankfurt am Main, Germany: 303.

Taylor, E. H., 1950. The Snakes of Ceylon. The University of Kansas Science Bulletin, 33 (2): 519603.

Vogel, G. and P. David, 2006. On the taxonomy of the Xenochrophis piscator complex (Serpentes, Natricidae), In: Herpetologia Bonnensis II: Proceedings of the $13^{\text {th }}$ Congress of the Societas Europaea Herpetologica, Vences, M., J. Köhler, T. Ziegler \& W. Böhme (eds.): 241-246.

Wall, F., 1921. Ophidia Taprobanica or the Snakes of Ceylon. H.R. Cottle, Government Printer, Ceylon: 581.

Wickramasinghe, L. J. M., R. Rodrigo, N. Dayawansa and U. L. D. Jayantha, 2007. Two new species of Lankascincus (Squamata: Scincidae) from Sripada. Zootaxa, 1612: 1-24.

Whitaker, R. and A. Captain, 2004. Snakes of India, The field guide. Draco Publication Limited. India: 479. 


\section{PLATE 01}

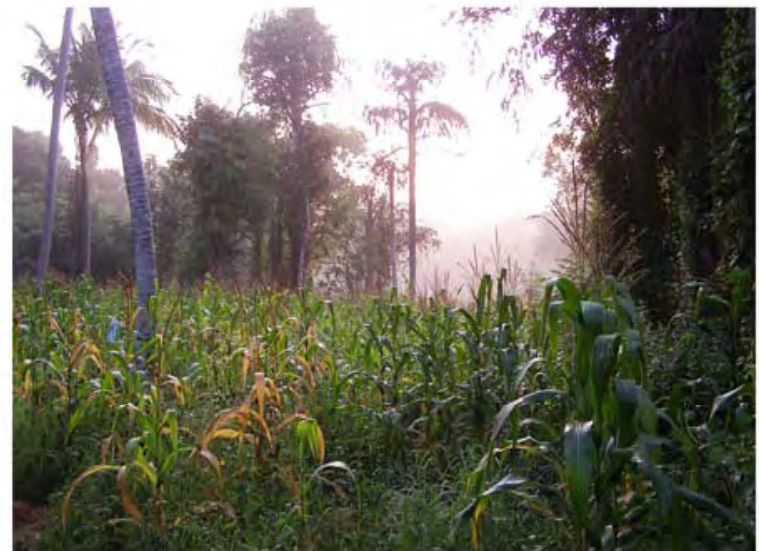

Fig. 03: Chena cultivations

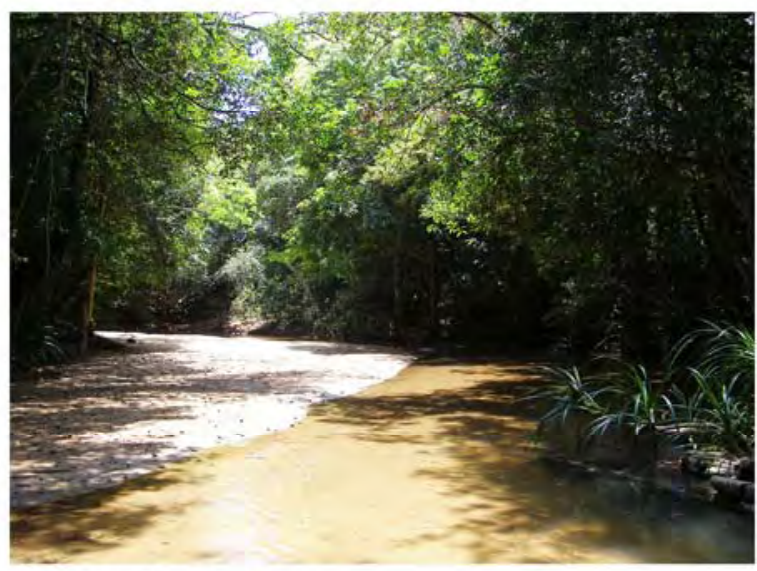

Fig. 05: Riverine forests

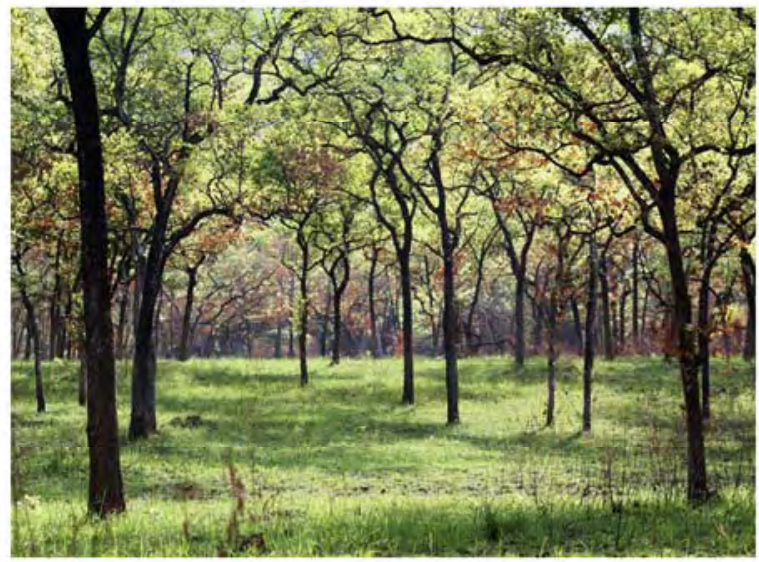

Fig. 07: Savannah forests

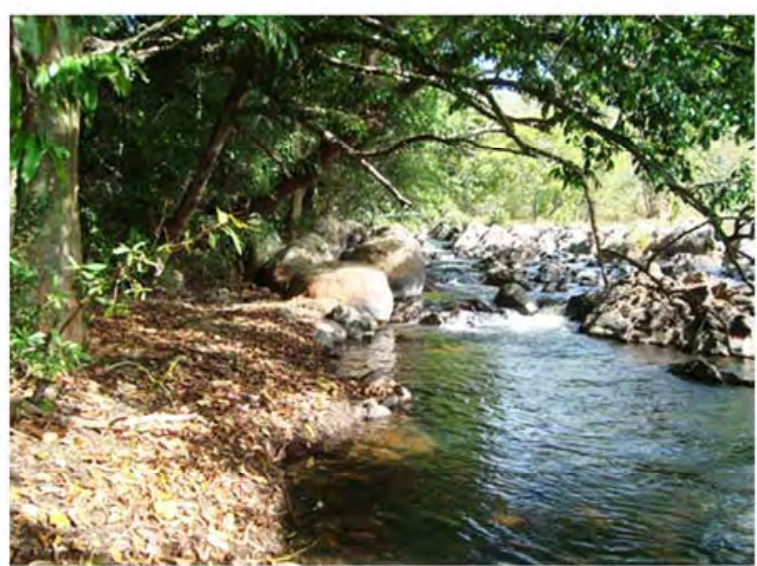

Fig. 09: Streams

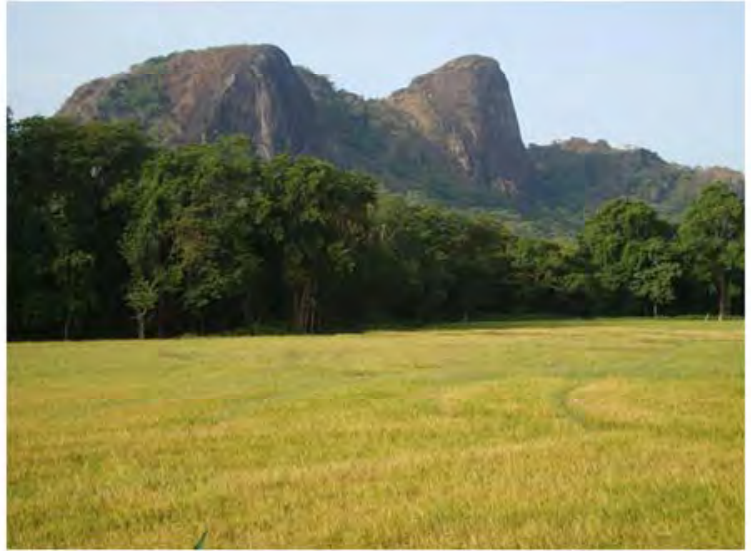

Fig. 04: Paddy fields

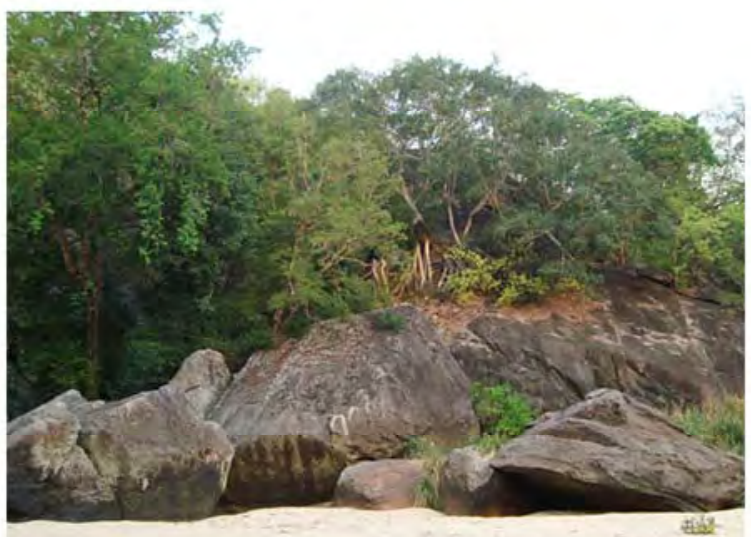

Fig 06: Rock-outcrops

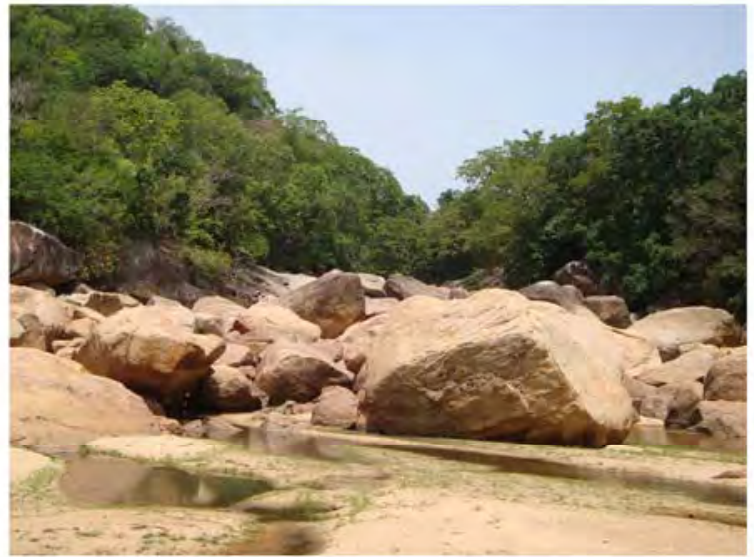

Fig. 08: Small Ponds

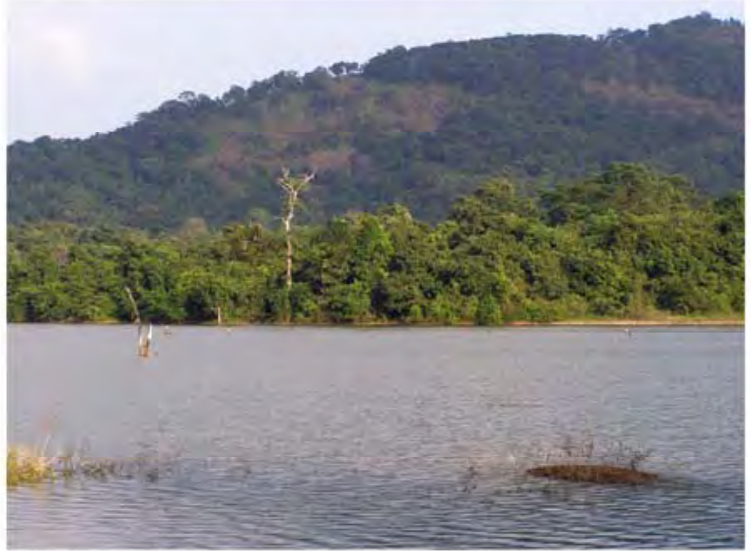

Fig. 10: Tanks 


\section{PLATE 02}

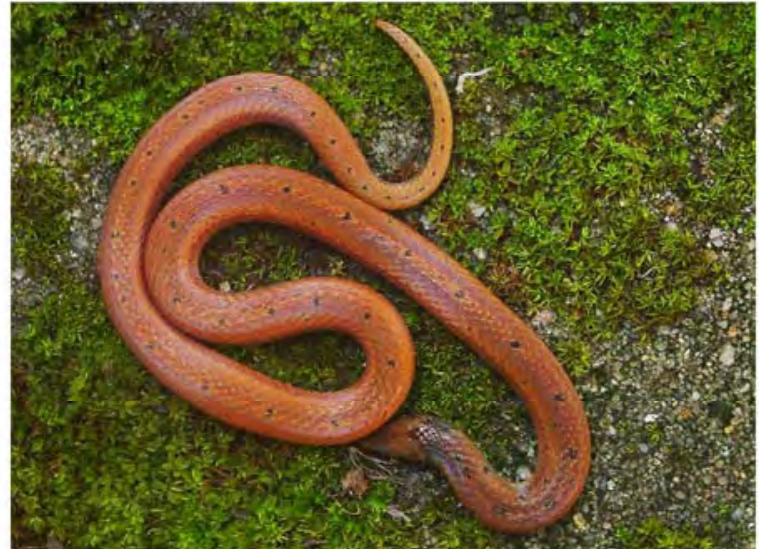

Fig. 11: Aspidura brachyorrhos

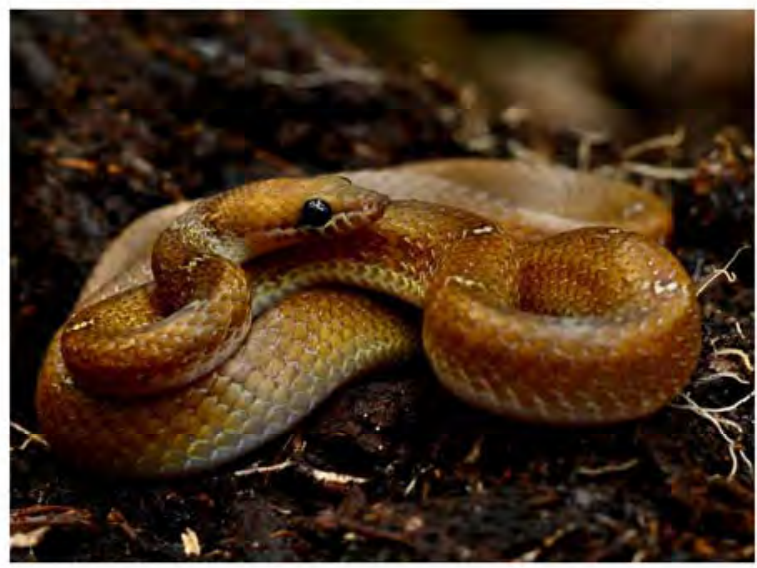

Fig. 13: Lycodon osmanhilli

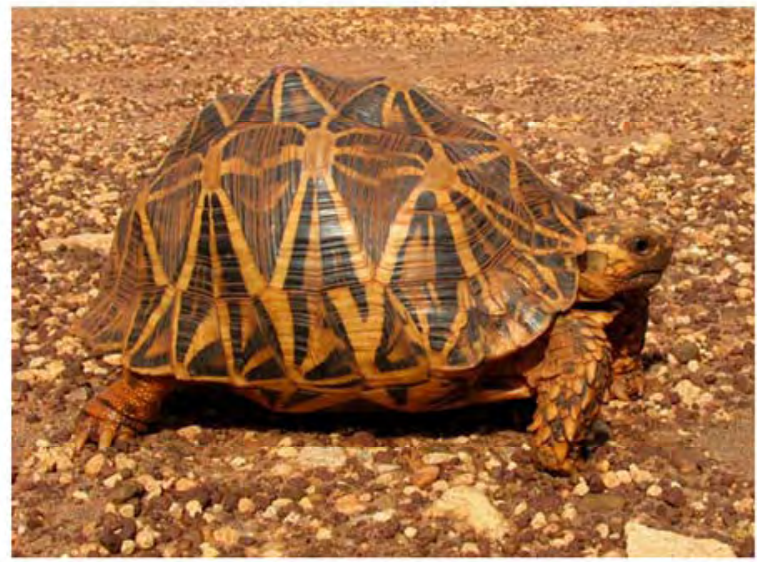

Fig. 15: Geochelone elegans

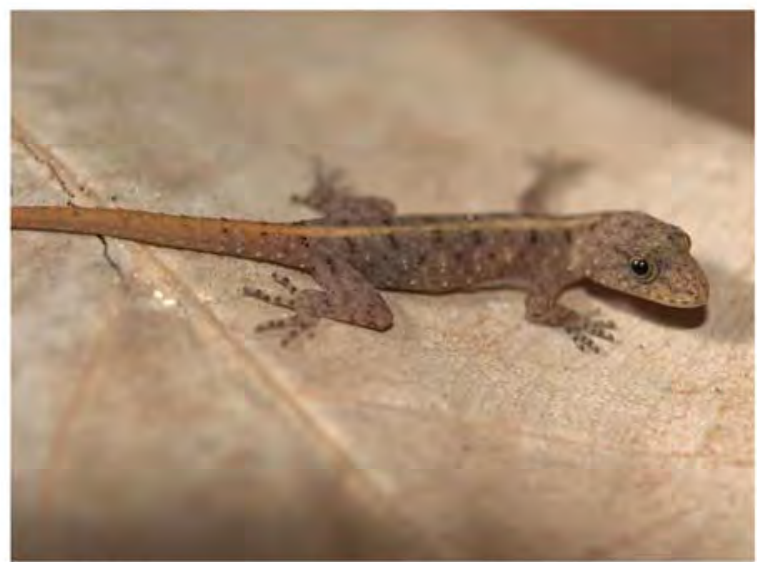

Fig. 17: Cnemaspis cf. tropidogaster

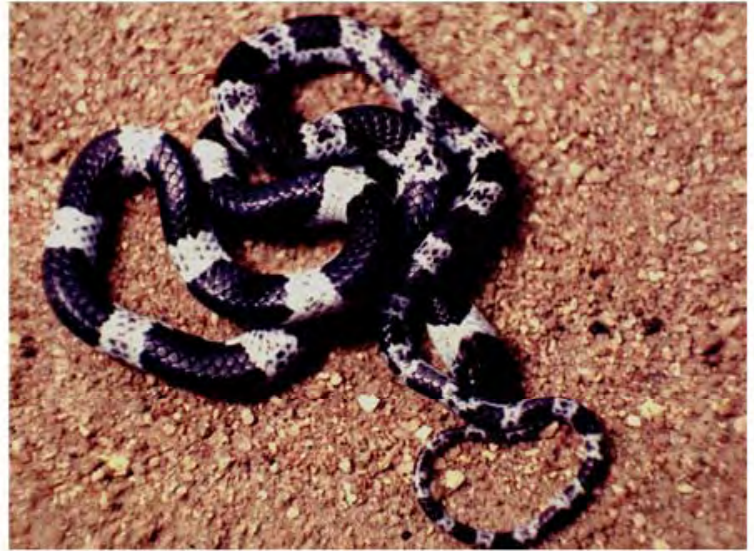

Fig. 12: Dryocalamus nympha

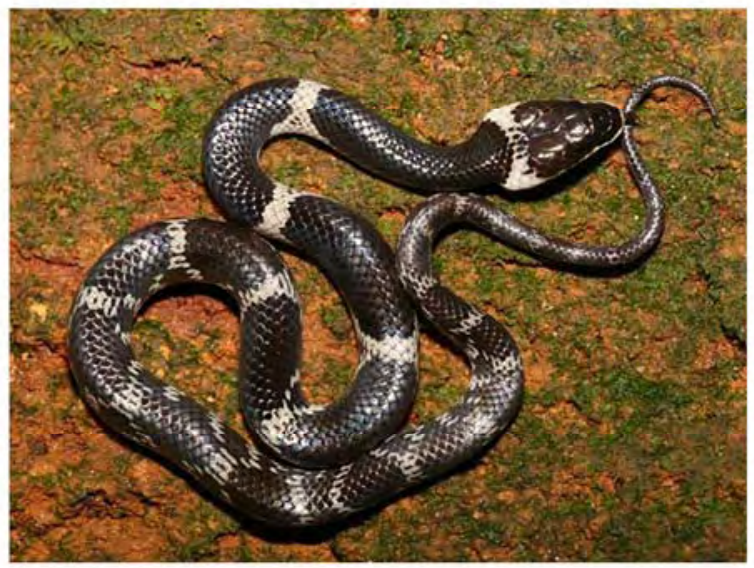

Fig 14: Lycodon striatus

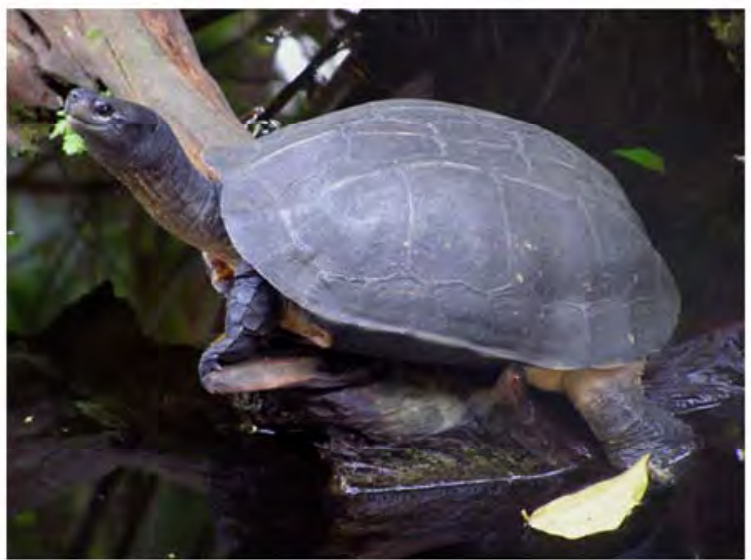

Fig. 16: Melanochelys trijuga

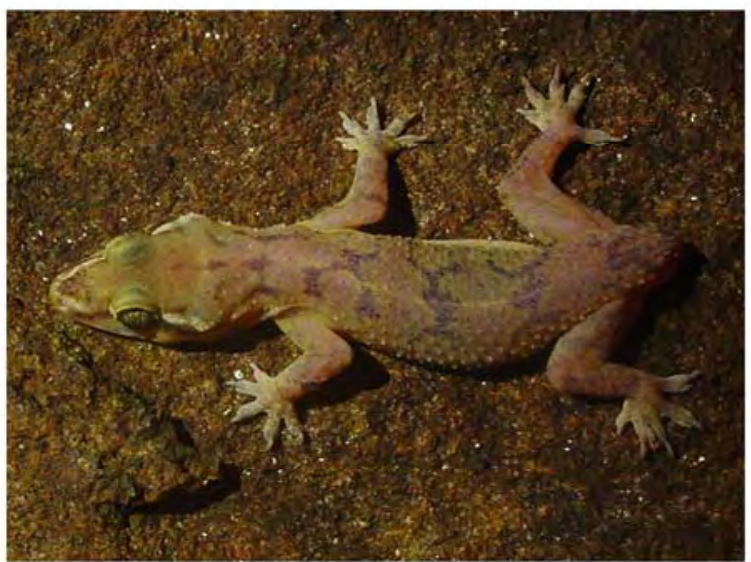

Fig. 18: Hemidactylus depressus 


\section{PLATE 03}

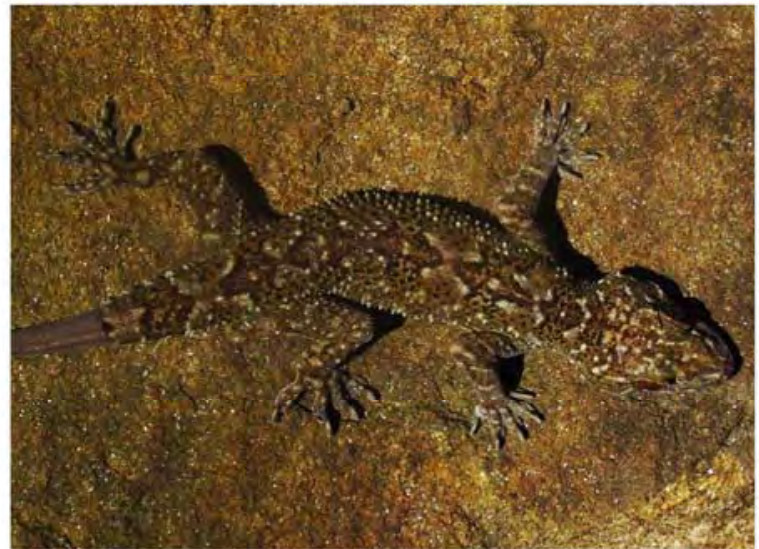

Fig. 19: Hemidactylus hunae

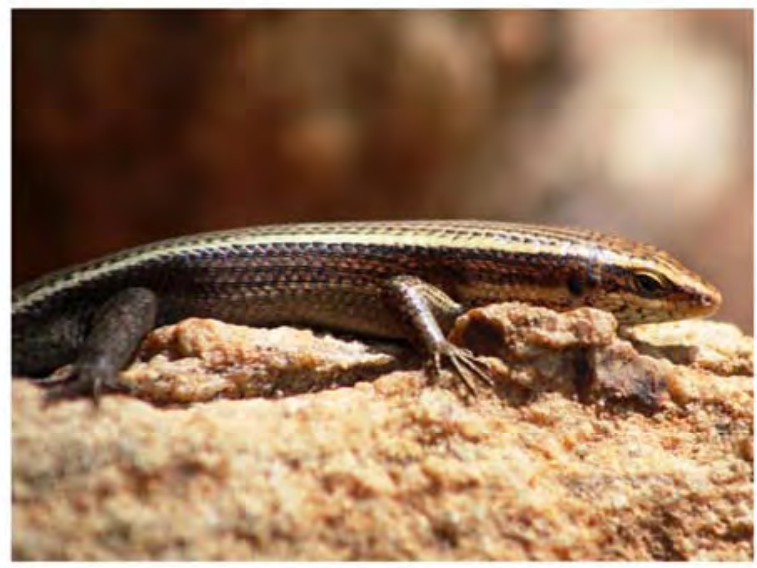

Fig. 21: Eutropis beddomii

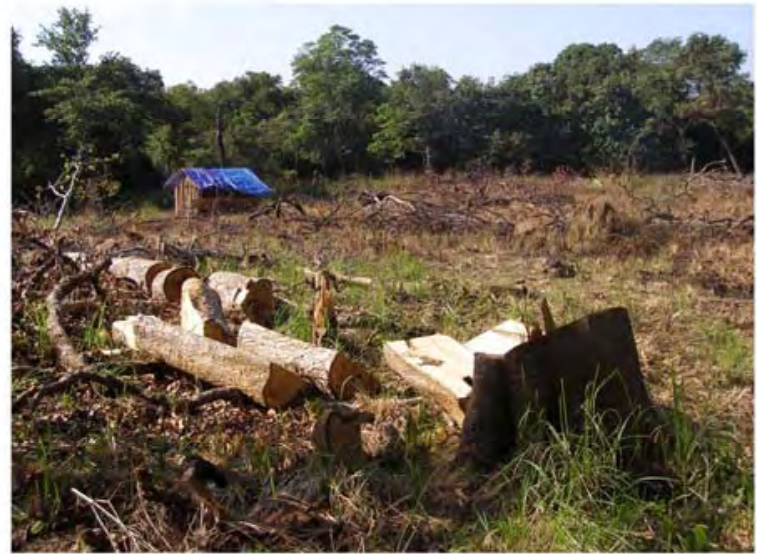

Fig. 23: Illegal logging

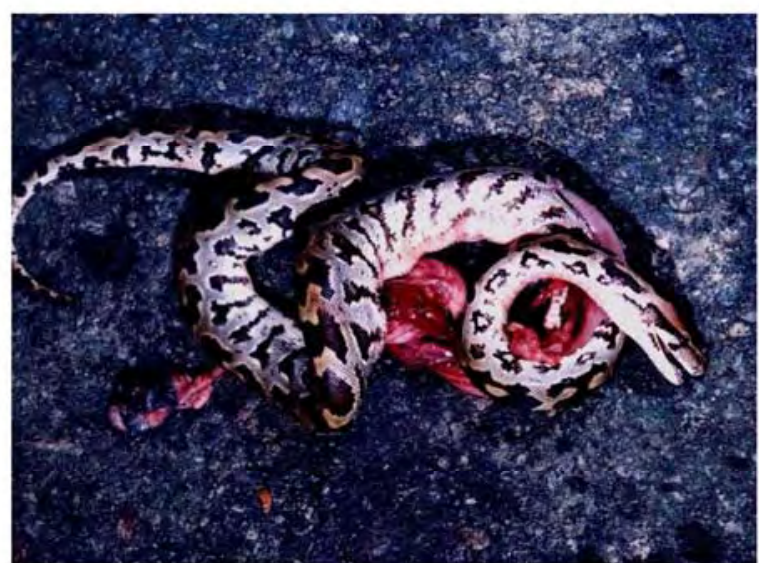

Fig. 25: Road kills

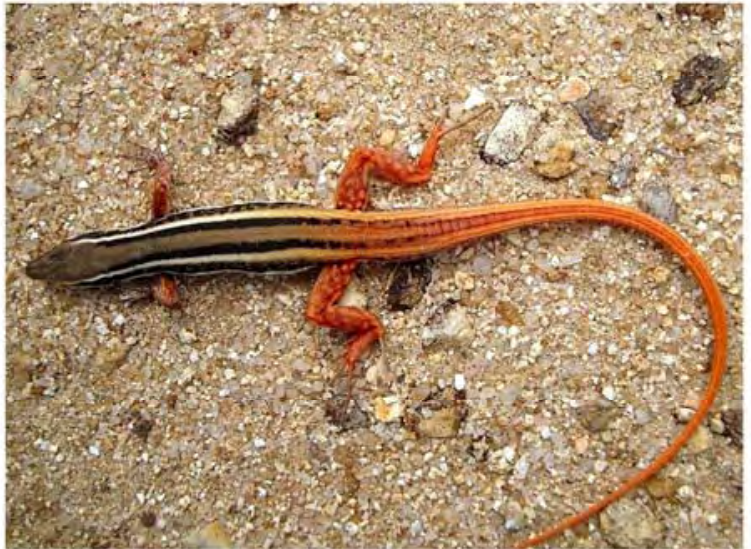

Fig. 20: Ophisops leschenaulti lankae

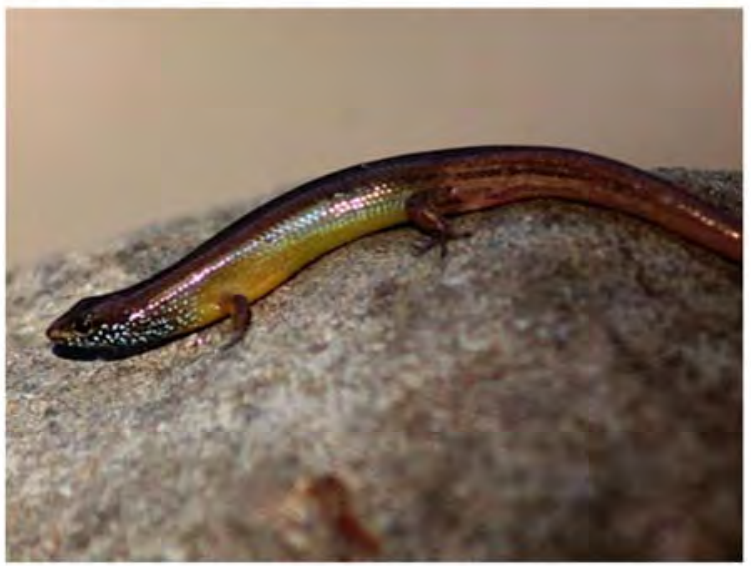

Fig 22: Lankascincus fallax

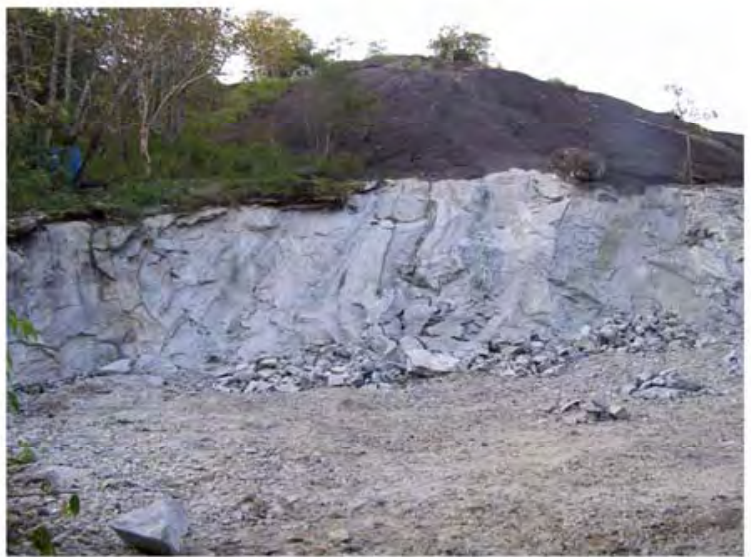

Fig. 24: Granite rock blasting

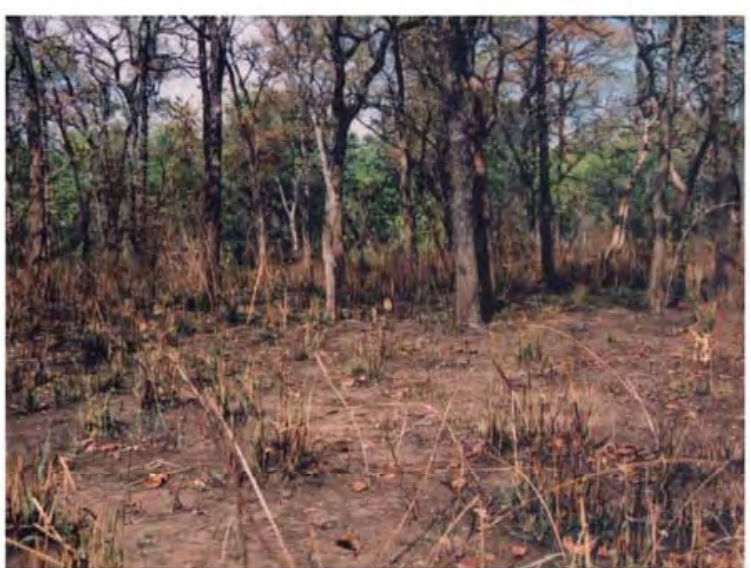

Fig. 26: Man made fire 